30

31

32

33

34

35

36

\title{
Historical land use and stand age effects on forest soil properties in the Mid-
} Atlantic US

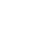

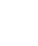

\author{
Yesilonis, $1^{1}$, K. Szlavecz ${ }^{2}$, R. Pouyat ${ }^{3}$, D. Whigham ${ }^{4}$, L. Xia ${ }^{2}$
}

${ }^{1}$ USDA Forest Service, 5523 Research Park, Suite 350, Baltimore, MD 21228, USA

2 Johns Hopkins University, Dept. of Earth and Planetary Sciences, Olin Hall 226, 3400 N. Charles St.

Baltimore, MD 21218, USA

${ }^{3}$ U.S. Department of Agriculture, Forest Service, Research \& Development, 1400 Independence Ave SW, Washington, DC 20250.

${ }^{4}$ Smithsonian Environmental Research Center, 647 Contees Wharf Rd, Edgewater, MD 21037, USA

16

17

Corresponding author: Ian D. Yesilonis (tel: 001443543 5381; email: iyesilonis@fs.fed.us)

Number of words in abstract: 246; text: 6377; Number of Figures: 5; Number of Tables: 2;

Supplementary material: 1.

Running title: Land use and age effect on soil

Keywords: Forest, land-use change, agriculture, forest age, nutrients

(C) 2016. This manuscript version is made available under the Elsevier user license http://www.elsevier.com/open-access/userlicense/1.0/ 


\section{Abstract}

The conversion of agriculture lands to forest has been occurring in parts of North America for decades.

41 The legacy of management activity during this transition is reflected in soil physical and chemical

42 properties years after abandonment. This study was conducted at the Smithsonian Environmental

43 Research Center, Maryland, USA, to determine land-use history and forest age effects on soil nutrients,

44 carbon, $\mathrm{pH}$, and bulk density. Soils in young and old successional forests and forests with no evidence of

45 historical disturbance were sampled. The young forest stands were abandoned from agriculture 50-70

46 years ago and the old forest stands had been abandoned from agriculture or grazing 120-150 years ago.

47 The oldest forest stands had no recorded history of disturbance even though it is likely they were at

48 least disturbed by tree removal or grazing of animals in the colonial era. Young forest soils had higher

49 concentrations of $\mathrm{Mg}, \mathrm{Ca}, \mathrm{NO}_{3}$ and a higher $\mathrm{pH}$ than old, which may be an age effect. The old forest soils

50 that had been abandoned from agriculture and grazing had higher bulk density and lower $\mathrm{C}$ content

51 than undisturbed stands indicating a land-use effect. In the stands that were formally agriculture there

52 was evidence of erosion, indicated by a Bt horizon closer to the surface. The most evident difference

53 between stands of different land-use history was the absence of a well-developed O horizon, which we

54 attribute to the presence of earthworms. Land-use legacy set the forest ecosystem in a different

55 trajectory of soil evolution.

56

\section{1. Introduction}

59 Land-use history has long term, if not permanent, effects on vegetation and soil properties (e.g.

60 Compton and Boone, 2000; Dupouey et al., 2002; Foster and Aber, 2003; Verheyen et al., 1999). The

61 duration and type of land use, e.g., woodlot, agriculture, and grazing, determines the current soil 
63 of land-use change has rendered differences in soil properties directly related to the duration of forest,

64 grassland, cultivated, and arable land (Verheyen et al., 1999). In the U.S., the recorded land-use history,

65 although not as extensive, is around 400 years but only for the northeastern coastal areas of the

66 country. Within this time frame these effects have been measured and have shown a long lasting

67 signature in the soil (Foster and Aber, 2003) and vegetation (Thompson et al., 2013) due mostly to the

68 impact of agriculture introduced during European settlement (Cronon, 1983; Foster and Aber, 2003).

69 Based on these studies in New England and Europe, it is clear that historical land uses profoundly

70 altered soil chemical and physical properties, including patterns of surface soil horizon development.

71 Some of the earliest colonial settlements were in the Chesapeake Bay region of Maryland. Before

72 European settlement, 95\% of Maryland was covered with forests (Besley, 1916). In the Chesapeake Bay

73 watershed, $40-50 \%$ of the land was under agriculture by 1840 (Cooper, 1995), increasing to $80 \%$ by the

74 end of the $19^{\text {th }}$ century (Brush, 1986). Currently the forest cover in Maryland is estimated to be $43 \%$ of

75 the land area (Stolte et al., 2012). The vast majority of forests in Maryland are secondary at different

76 stages of succession with varying tree species composition (Brush, 1986). At the Smithsonian

77 Environmental Research Center (SERC) in Anne Arundel County, MD, where our research was

78 conducted, there are uncut forest stands which provide a rare opportunity to study the effects of land-

79 use history on the trajectory of soil recovery post anthropogenic disturbances. Here we report on a

80 comparative study in thirteen forest stands at SERC focusing on the changes in soil physical and chemical

81 properties over a 150-year period.

82 SERC lies within the watershed of the Rhode River sub-estuary of Chesapeake Bay. The Smithsonian

83 owns 1072 ha on the Rhode River watershed and the land is maintained in a mix of land-uses, including

84 forest stands that have no physical evidence of previous disturbance, stands of mature forests with

85 evidence of previous disturbance and forests that have been undergoing succession since the stands 
were abandoned from agriculture in the 1940s. Advantages of conducting our study at SERC include: (1)

87 Information on historical uses of the SERC land goes back to the time of European colonization in the 1600's, (2) SERC soil, land use, and vegetation history has been documented (Correll, 1974; Higman, 1968; Pierce, 1974), (3) SERC upland forests are a patchwork of stands of different ages reflecting different times of agricultural abandonment, and (4) small stands of uncut, old growth exist on the property.

Soil formation and soil evolution is a slow process, thus most chronosequence studies have implemented a space-for-time substitution. This approach has been criticized for the lack of consistency 94 in controlling for abiotic and biotic conditions through time (Johnson and Miyanishi, 2008; Pickett, 1989). Despite these difficulties, we believe detailed knowledge of historic land-use patterns can provide a valuable platform for evaluating ecosystem structure and function, especially as they related 97 to differences in soil characteristics.

Our approach was to characterize and compare physical and chemical soil properties of forest stands that differed in age and land-use histories on the SERC property. Our objectives were to determine: (1) the degree to which forest soils retain legacy impacts from past agricultural practices and 101 (2) the degree to which the legacy impacts change over time. We developed a conceptual model to separate the complex interaction effects of stand age, land-use legacy, and other disturbances to understand the present-day soil characteristics and therefore, the trajectory of soil evolution (Figure 1).

104 The well-documented history of the upland forest mosaic of SERC are a great opportunity to advance our understanding of how forest soils recover in this region. During colonial times and later, many of the forest stands in the area were converted into agriculture fields. This conversion from forest to long-

107 term crop production introduced physical disturbance associated with annual cultivation, nutrient amendments from fertilizer and manure, and bioturbation by introduced soil fauna, mainly non-native 
transformation in soil properties varied by differences of age, we compared young and old forest soils,

111 and for differences related to land use, we compared soils in the young/old to the uncut forests. Unique

112 aspects of this study compared to existing land-use history studies are the comparison of land-use

113 histories, forest ages, and uncut forest stands on similar soil types; and the establishment of non-native

114 earthworm communities in both the young and old forest soils but not the uncut forest soils.

115 Based on the conceptual model shown in Figure 1, to compare age effects, we expected that old

116 forest stand soils would have higher carbon, lower nutrient concentrations, bulk densities and $\mathrm{pH}$ than

117 the young forest soils. Exposure to weathering and vegetation differences would cause the net loss of

118 nutrients in the old forest soils compared to the young forest soils. To compare land-use effects, we

119 expected that uncut forest soils would contain more SOM related to a thicker O horizon than the old

120 forest stands. We also predicted that uncut forest would have less nutrients, and lower bulk densities

121 and $\mathrm{pH}$ than the old forest soils through a combination of weathering, lower quality leaf litter, lack of

122 additional nutrient input from historical cropping and grazing practices, and lack of earthworm mixing

123 and feeding activity.

124

125 2. Methods

126

2.1. History and description of the Smithsonian Environmental Research Center

The Smithsonian Environmental Research Center (SERC) is located along the western shore of the

130 Chesapeake Bay in southern Anne Arundel County, Maryland on the Rhode River estuary $\left(38^{\circ} 53^{\prime} \mathrm{N}\right.$,

$13176^{\circ} 33^{\prime} \mathrm{W}$ ) (Figure 2). The major soils at SERC are Collington sandy loam (fine-loamy mixed, active, mesic

132 Typic Hapludult), Annapolis fine sandy loam (fine-loamy, glauconitic, mesic Typic Hapludult) and

133 Donlonton fine sandy loam (fine-loamy, glauconitic, mesic Aquic Hapludults) (Supplementary material 
Appendix A)(NRCS, 2015, Dec 1). The parent material is glauconitic marine sediments lying on the

135 Nanjemoy formation. The mean precipitation in the region is $114.6 \mathrm{~cm}$ and the mean annual temperature is $13^{\circ} \mathrm{C}$ (D. Correll, T. Jordan, and J. Duls, unpublished data). Elevation change across SERC

137 is minimal, 15-30 meters (Correll, 1974).

Land use, vegetation, and management history (Higman, 1968) and soils (Correll, 1974; Pierce, 1974)

have been examined and measured at SERC. Land-use maps were available from 1846 and more

recently from 1925 and the late 1960's. The earliest pictorial record in 1846 of the Rhode river

watershed is a topographic map published by the US Coast and Geodetic Survey (Table 1). These maps distinguish between forests (deciduous and conifer), farmland, wetland and residential areas. Later, aerial photos taken by the USDA, US NAVY and NASA, and vegetation and soil surveys were used to

144 construct vegetation and land use maps by the staff of the Smithsonian Environmental Research Center

145 (Higman, 1968; Jenkins et al, 1971; Correll, 1974; Pierce, 1974). Oral history of the property was recorded in 1970s and compiled by Daniel Higman (unpublished). The 13 sites selected for this study were comprised of 5 young, 5 old and 3 uncut forest stands using vegetation survey data and map prepared by Higman (1968) (Figure 2). We used age-range categories because (1) we would have replicates for statistical analysis, and (2) the exact ages of the forest stands are unknown. Based on historical documents and examination of tree rings of trees that had been felled, it was possible to place 151 the stands into distinct age categories. Both young and old forest stands have been classified as part of 152 the Tulip poplar Associations (Brush et al., 1980), but they differ in age and tree species composition.

154 with diverse crops fertilized with manure, marl, and gypsum (Higman, 1968) until the mid-20 ${ }^{\text {th }}$ century, 155 then abandoned (Table 1). Details about timing, frequency, and exact location of the amendment are 156 not known. Today these stands are at least 50 years old, dominated by tulip poplar (Liriodendron 157 tulipifera) and sweet gum (Liquidambar styraciflua), with red maple (Acer rubrum), black cherry (Prunus 
serotina) and box elder maple (Acer negundo) being the secondary species. The first two species

159 comprises $71 \%$ of the leaf litter production (Szlavecz unpublished data). The old forest stands developed 160 on lands that were abandoned from management about 120-150 years ago and have a mixed history of 161 agriculture and logging. Tulip polar and sweet gum are still important canopy species in these stands but 162 the dominant trees are several species of oaks, (Quercus spp.), American beech (Fagus grandifolia), and 163 hickories (Carya spp.); making up 62\% of the leaf litter production (Szlavecz unpublished data). The 164 uncut forest stands were classified and mapped as the Chestnut oak-Chestnut Association (Brush et al., 165 1980). They are considered to be the oldest forests on the SERC property and there is no evidence of 166 previous management activities such as agriculture and logging (Higman, 1968). The uncut forests are 167 dominated by several species of oak (Quercus) with the dominant species being chestnut oak (Q. prinuS) 168 which contributes $70 \%$ of the total litter input (Szlavecz unpublished data).

Previous research by our group has demonstrated that non-native earthworms are an important component of SERC forests (Crow et al., 2009; Filley et al., 2008; Ma et al., 2013; Szlavecz and Csuzdi, 171 2007; Szlavecz et al., 2011). In the context of this study, the uncut forests on Hog Island, Fox Point and 172 Big Island are earthworm-free while non-native earthworms are abundant in soils at the old and young 173 forest stands (Szlavecz and Csuzdi, 2007; Szlavecz et al., 2011).

174 There is no evidence that the forests at the Frog Canyon and Weir sites were ever cleared for 175 agriculture but they were grazed by cattle from 1915 to 1940 when SERC operated as a dairy farm (Java 176 Dairy Farm, n.d.). The understory vegetation at the Frog Canyon and Weir sites lack the understory 177 herbs and shrub species that are found in mature forests at the Tower, Treefall and Triangle sites (Figure 178 2) where there is no evidence of grazing during the period of time that the dairy farm operated. The 179 Tower, Triangle and Treefall sites, however, show evidence that they may have been grazed prior to the 180 Civil War. All three sites have very large canopy trees which have canopy growth forms typical of trees 181 that grew in the open (i.e., not in a closed forest). The other canopy trees at those sites are, however, 
182 large and based on size and age probably colonized the site about the time that the Civil War. If these

183 historical interpretations are correct, the young and old forest stands were both grazed. There is also

184 some historical evidence, stumps and information from the previous land owner of the Treefall site that

185 trees may have been selectively removed from that part of the forest within the past 50-100 years,

186 however, it does not appear that it was ever clear cut.

187

\subsection{Soil sampling and analysis}

Soil was sampled from five young five old and three uncut forest stands. The uncut forest stands

191 although somewhat different is tree composition, represent undisturbed conditions, and thus were used

192 to compare soil properties to those soils once supporting agriculture or other human activities such as

193 logging and grazing. The soils series catena and topography are similar throughout the study area in

194 order to minimize confounding conditions. For example, the soil series of Annapolis fine sandy loam,

195 Collington sandy loam, and Donlonton fine sandy loam are similar enough for comparison purposes

196 even though there is different vegetation in the young, old, and uncut forest stands. All sampling sites

197 were on slopes less than 5\% except for Weir where it was greater.

198 In order to determine the depth of the Bt horizon, a representative $10 \times 10 \mathrm{~m}$ area of the particular

199 forest stand was selected and 9 soil samples 5 meters apart were cored per site. The depth of the Bt

200 was determined using texture analysis by the feel method. Slope was also taken using a clinometer both

201 in the direction of greatest slope and perpendicular to account for the influence of topography on Bt

202 depth.

203 For texture and chemical analysis, composite samples, which combined fifteen $3.5 \mathrm{~cm}$ diameter soil

204 cores from each of the 13 stands, were taken of the mineral soil from $0-10 \mathrm{~cm}$ and $10-20 \mathrm{~cm}$.

205 Additionally, $25 \times 25 \mathrm{~cm}$ quadrats of the organic horizons of the uncut forest soils were collected and 
placed in a drying oven at $70^{\circ} \mathrm{C}$ until constant weight. Mean values per site were used to calculate mean

207 and standard error on Table 2. Morgan-extractable chemical characteristics ( $\mathrm{P}, \mathrm{K}, \mathrm{Mg}, \mathrm{Ca}, \mathrm{Fe}, \mathrm{Al}, \mathrm{Mn}, \mathrm{Zn}$, 208 and $\mathrm{NO}_{3}$ ) were determined at the Cornell Soil Analysis Laboratory. Bulk density for the top 0-5 cm was 209 determined by a gravimetric coring method (Blake and Hartge, 1986); texture was determined by the 210 hydrometer method (Wilde et al., 1972); $\mathrm{pH}$ was determined in 1:1 $\mathrm{H}_{2} \mathrm{O}$. Soils were analyzed for $\mathrm{C}$ and $\mathrm{N}$ 211 content using an EAI CE-440 elemental analyzer (Exeter Analytical Inc.) at the Analytical Services

212 Laboratory at SERC. Carbon for the organic O horizon layer was determined by loss on ignition. Carbon 213 content was calculated using $\mathrm{C}$ percentage and bulk density and summing the $\mathrm{O}$ horizon layer (where 214 present) and the mineral layer.

\subsection{Statistical Analysis}

Principle Component Analysis (PCA) was used as a data reduction tool to explain variability and to visualize the comparison of forest stands spatially using SAS Proc FACTOR. The number of soil chemical variables chosen to represent each principle component was determined using the eigenvalue for a

221 given principle component. Due to high degree of autocorrelation, which is common in soils, and low 222 replication of study sites ( $n=13$ composite samples), a subset of the 16 variables was selected for the 223 surface depth and of the 13 for the lower depths (Table 2). For the surface depth, $\mathrm{P}, \mathrm{pH}, \mathrm{Ca}$, clay, bulk 224 density, $\mathrm{C}$ content (the $\mathrm{C}$ content accounted for the $\mathrm{O}$ horizon layer and the bulk density of the $\mathrm{O}$ 225 horizon and mineral soil layer), and $\mathrm{N}$ were chosen. For the lower depth $\mathrm{P}, \mathrm{pH}, \mathrm{Ca}$, clay, $\mathrm{C}$ percent, and 226 N were selected. These variables serve as surrogates for the other measured soil variables, for example, 227 divalent Ca was used in lieu of divalent $\mathrm{Mg}$; clay for sand and silt, C content for C percent and C:N ratio, 228 and $\mathrm{pH}$ for Al. Differences in soil characteristics between young, old, and uncut forest stands were 229 analyzed using the restricted likelihood estimation technique SAS Proc MIXED and GT2 Hochbergs pair- 
wise comparisons. The fixed effects were forest stands, there were no random effects in this completely randomized design, and each of the two soil depths was run separately (SAS, 2010). Residual evaluation

232 for normality and homogeneity of variance were not tested due to low sample size per group, i.e., young

$233 n=5$, old $n=5$, and uncut $n=3$. Normality tests have little power, when the sample size is low, to

234 determine if a sample comes from a Gaussian population. Small sample sizes do not provide reliable 235 inferences about the shape of the distribution in the entire population. Regression analysis was done in 236 GraphPad Prism. For figure 5, a second order polynomial equation, $Y=632+(-283)^{*} X+31.53^{*} X^{2}$, was 237 used to create the regression line.

\section{Results}

\subsection{Soil physical properties}

242

The old and young stands had an Ap horizon and the uncut stands had an A horizon. All had a clay-

244 rich Bt horizon, with soils at some sites also having a transition horizon. The transition to the Bt horizons 245 (Table 2) in the old forest stands was deeper $(25 \pm 2.0 \mathrm{~cm})$ than the young forest stands $(18 \pm 3.7 \mathrm{~cm})$.

246 The deepest transition from surface to subsurface horizons was in soils at the uncut forest stands ( $40 \pm$

$2472.0 \mathrm{~cm})$. There was a negative correlation $\left(r^{2}=0.45, p=0.049\right)$ between the percent clay in the surface 248 soils and the depth of the top of the Bt horizon (Figure 3).

249 All of the young forest stands had a similar pattern of clay accumulation throughout the profile 250 starting at the surface (9\%) and increasing to the $25 \mathrm{~cm}$ depth (33\%). This same pattern was found in 251 soils at the old forest stands but the variance in the percent clay was higher. Along with clay content or, 252 in part, due to the amount of clay, there were forest stand differences in bulk density. The uncut forest 
soils had significantly $(p=0.009)$ lower bulk density than the old $(48 \%)$ and young $(57 \%)$ forest stands,

254 respectively (Table 2 ).

255

\subsection{Soil chemical properties}

257

For the surface $10 \mathrm{~cm}, \mathrm{Ca}, \mathrm{pH}$, bulk density explained $46 \%$ of the variability, followed by carbon content and $\mathrm{N}$ which accounted for $19 \%$ (Figure $4 \mathrm{~A}$ ). The forest sites formed three distinct groups with uncut forest stands separated from the young and old stands that had been historically managed. The young forest soils with a history of agriculture use have higher $\mathrm{pH}, \mathrm{Ca}$, and bulk density (Table 2). The uncut forest soils had the lowest $\mathrm{pH}, \mathrm{Ca}$, and bulk density with the old forest soils falling between the

263 young and uncut forest soils. For the $10-20 \mathrm{~cm}$ depth, $\mathrm{Ca}$ and $\mathrm{P}$ explained $39 \%$ of the variability,

264 followed by clay which accounted for 23\% (Figure 4B). One distinction between the young forest and 265 the old and uncut stands was that the young stands have higher concentrations of Ca and lower P. 266 However, it did not appear that texture, e.g. clay, in the $10-20 \mathrm{~cm}$ soil layer explained the differences 267 related to forest age, even though there were differences in the depth to the Bt horizon (18 $\mathrm{cm}$ for 268 young, 25 for old, and 40 for uncut) between forest stands; soil samples for the texture analysis were 269 taken above the Bt horizon.

270 The $\mathrm{pH}$ in the surface $0-10 \mathrm{~cm}$ at the young forest stands was 5.4 ; this was $13 \%$ and $41 \% \log$ units 271 higher than $\mathrm{pH}$ in the old and uncut forest soils, respectively (Table 2). Calcium concentrations of soils 272 at the young forest stand $\left(2400 \mathrm{mg} \mathrm{kg}^{-1}\right)$ were $58 \%$ and $98 \%$ higher than soils at the old and uncut forest 273 stands, respectively. A C:N of 12.2 in the young forest soils was $32 \%$ and $53 \%$ lower compared to soils at 274 the old and uncut forest stands, respectively. Bulk density in the young forest soils $\left(1.0 \mathrm{~g} \mathrm{~cm}^{-3}\right)$ was $18 \%$ 275 and $57 \%$ higher than the old and uncut, respectively. The $10-20 \mathrm{~cm}$ soils showed the same trends 276 except for the C:N ratio which was not statistically different (Table 2 ). The carbon content in the uncut 
277 forests soils was significantly higher than the old forest soils. The uncut forest had an O horizon mass of

$278 \quad 3.6 \pm 0.6 \mathrm{~kg} \mathrm{~m}^{-2}$, whereas the old had a small or absent $\mathrm{O}$ horizon, and the young forest had no $\mathrm{O}$

279 horizon.

280 Soils at the young forest stands for the surface $0-10 \mathrm{~cm}$ had 74 and 11 times higher base cation (BC):

281 aluminum (Al) ratios than soils from the uncut and old stands respectively (Figure 5A, Table 2). The base

282 cations were the sum of $\mathrm{Ca}, \mathrm{Mg}$, and $\mathrm{K}$. Both the uncut and old forests had $\mathrm{BC}: \mathrm{Al}$ ratios that did not

283 change with an increase in $\mathrm{pH}$, however, the young forest $\mathrm{BC}$ : $\mathrm{Al}$ ratio increased with $\mathrm{pH}$. This ratio

284 increased after a pH of approximately 5.2 in the surface $0-10 \mathrm{~cm}$ depth. The BC:Al ratios were also

285 significantly higher at the $10-20 \mathrm{~cm}$ depth interval at the young forest stands compared to the old and

286 uncut (Figure 5B, Table 2). In the 10-20 cm lower depth, there was less of a response between $\mathrm{pH}$ and

287 the BC:Al ratio in the young forest stands.

288

289

4. Discussion

290

Soils integrate long- and short-term history through soil physical and chemical characteristics,

292 biological activity, and spatial landscape arrangement (Fanning and Fanning, 1989). Important

293 ecosystem processes, such as $\mathrm{C}$ storage and $\mathrm{N}$ retention, are influenced by soil properties and reflect

294 historical patterns of land use (Compton and Boone, 2000). This integration over various time scales

295 complicates the interpretation of the influences from different land-use histories and cover types even if

296 other soil forming factors are held constant. Given the inherent drawbacks of space-for-time studies

297 (Pickett, 1989), our study area was distinct because soils from stands with no previous land-use history

298 represented a baseline for comparison with soils that had different patterns of land-use management

299 and different recovery times. 
At SERC, three of the five main factors related to soil formation were similar: parent material,

301 climate, topography (Jenny, 1941). The primary differences between the three sets of stands were time

302 since disturbance and organisms that include vegetation and soil biota that affect soil development in

303 multiple ways (Figure 1). The three forest stands have had different histories related to agriculture or

304 use such as grazing. The young forest stands had been previously cleared and managed as agricultural

305 fields for many decades. The old forest stands had a wider range of historical land uses including

306 agriculture and grazing. Verheyen et al. (1999) showed historical grassland combined with other land-

307 use classes affected soil chemistry. Both Frog Canyon and Weir (old forest sites) were grazed by cattle

308 when the sites were a dairy farm; however, we found no differences in soil nutrient concentrations

309 between the two grazed forest sites compared to the other old forest sites, which were similar to what

310 Fraterrigo et al. (2005) found between historic land use that was pasture and a forested reference.

311 Franzluebbers and Stuedemann (2013) suggested that animal grazing had no effect on C or N after six

312 years.

313

\subsection{Soil physical properties}

315

Our results demonstrate that, within the 150 -year time frame, both land-use history and forest age

317 have an influence and long-term effects on soil physical properties. The depth of the top of the Bt

318 horizon, which is defined as a layer of soil with increased clay content compared to the layer above, may

319 be an indication of erosion of the surface horizons such as the O, Ap, and AB (Reganold et al., 1987) for

320 the young and old stands. Erosion in the early stages of agriculture at SERC, i.e., 1670 (Java Dairy Farm,

321 n.d.), resulted in local laws being passed in 1704 and 1743 to prevent siltation of streams (Higman,

322 1968). The Bt horizon in young forest soils was closer to the surface compared to the uncut forest soils

323 (Table 2); this may indicate more wind or water erosion in combination with possible loss of organic 
324 matter due to oxidation. These results suggest that the physical effects of historic erosion may still be

325 present in these soils today. As the depth to the Bt decreases, the percent of clay in the surface

326 horizons increased (Figure 3). We propose that the depth of Bt horizon has the potential to be an

327 indicator for similar chronosequence studies focusing on old field succession. The timing and duration

328 of the erosion is speculative but regardless of when these events occurred, the soil horizons are

329 reflective of the cumulative effect of erosion.

The young forest soils have higher bulk density values compared to the old and uncut forest stands

331 which may be related to recent cultivation (Tiessen et al., 1982), to the foot and equipment traffic (Lyon

332 et al., 1952; Tiessen et al., 1982) related to sowing and harvesting, or, earthworm activity. Earthworms

333 can both compact and decompact soil (Blouin et al., 2013). The effects of earthworms on bulk density

334 will depend on (1) the initial conditions (e.g. highly compacted soil will become more loose by

335 earthworm activity), and (2) the earthworm species composition. Decompaction can be the result of

336 constant burrowing through the soil thus loosening it. Bulk density on the surface may increase when

337 species consistently deposit their loose, globular cast on the surface. Compaction on the surface

338 happens when the entire annual leaf litter input is consumed by the earthworms, and the casts are

339 mixed into the mineral layer. This has been observed in temperate, originally earthworm-free forests in

340 North America (e.g. Alban and Berry, 1994; Hale et al., 2005). At SERC, all leaf litter is consumed within a

341 year in the young forests.

\subsection{Soil chemical properties}

We expected old forest soils to have higher C; lower nutrients, bulk densities, and pH than the

346 young forest soils. We found that only $\mathrm{Mg}, \mathrm{Ca}, \mathrm{NO}_{3}$, and $\mathrm{pH}$ were significantly different between young

347 and old forest soils. For the land-use effect, $\mathrm{C}$ content and bulk density were the only variables that 
differed significantly between old and uncut forest. Differences in soil chemical properties may be the

349 result of the complex interactions of land use and forest age. Forests were cleared for agricultural use, 350 and after abandonment, succession led to the establishment of secondary forests. Consistent with

351 results from this study, others have demonstrated that during succession from abandonment of

352 agricultural fields to forests, carbon increases (Brunet et al., 2012; DeGryze et al., 2004; Falkengren-

353 Grerup et al., 2006; Flinn and Marks, 2007), pH decreases (Falkengren-Grerup et al., 2006; Schrijver et

354 al., 2012) and the C:N ratio increases (Compton and Boone, 2000). The young soils at the SERC stands

355 were less acidic and contained less Al compared to the old forest soils in both the surface and lower

356 depths. The $\mathrm{pH}$ of the uncut forest surface soil depth was very low, $18 \%$ lower than the average of the

357 old and young soils, and 14\% lower than the NRCS web soil survey (NRCS, 2015, Dec 1 ) estimations of

3584.9 (Collington has an estimated pH of 4.7, Annapolis, 5.4, and Donlonton, 4.5). The low pH in uncut

359 forests $\mathrm{pH}$ are probably due to a combination of decades of soil leaching in and lack of leaf litter input

360 high in nutrients such as calcium. Also, earthworms that have been shown to increase pH (Burtelow et

361 al., 1998; Szlavecz et al., 2006) are absent in the uncut sites. In the previously managed sites additional

362 factors influencing soil pH and Ca levels include amendment of manure, marl, and gypsum (Higman,

363 1968). To complicate matter at SERC, several oyster middens have been discovered (Cook-Patton et al.,

364 2014), which would directly increase $\mathrm{pH}$ and Ca; however to our knowledge, none of our sampling

365 locations overlapped with these relic middens.

366 There was a general increase in Mg and Ca concentrations in soils between the uncut, old, and

367 young forest stands, however, there were no differences in P concentration. This finding was not

368 consistent with the results of Bellemare et al. (2002) and Switzer et al. (1979) who found that Mg and Ca

369 concentrations in the surface soil increased with forest age. A possible explanation for the differences

370 between our study and the others may be related to earthworm activity and vegetation differences,

371 including understory (Higman, 1968) and herbaceous plants (Parker et al, 2010) thereby influencing the 
372 quantity and quality of leaf litter input, and therefore the nutrients to the soils. The young stands at

373 SERC were dominated by tulip poplar (Liriodendron tulipifera) which has leaves with higher

374 concentrations of $\mathrm{Mg}$ and Ca compared to oaks (Mudrick et al., 1994) which dominate the forest at the

375 old and uncut stands. Unlike studies that have found differences in P concentrations between historic

376 agricultural land and a reference forested stands (e.g.,Compton and Boone, 2000; Honnay et al., 1999;

377 Koerner et al., 1997; Verheyen et al., 1999), it was surprising to find no differences between the

378 historical agricultural stand, i.e., young and old, compared to the uncut stands especially since the

379 agricultural fields would have additional applications of manure high in P. The soil nutrient status has

380 been shown to be important to tree community organization in northeastern forest (Bigelow and

381 Canham, 2002), to diagnose nutrient deficiencies for sugar maple (Ouimet et al., 2013), and to model

382 coarse-scale plant species distribution in combination with climate variables (Coudun et al., 2006).

383 One difference between the old and uncut stands was that $C$ content was lower because clearing

384 and logging may have created more erosion in the old forest stands, and the earthworm population

385 prevented redevelopment of the O horizon (Ma et al. 2013). In uncut forest, cation concentrations may

386 be underestimated and may not be representative of the total cation content because the cation

387 content was not measured in the O horizon.

388 The old and uncut forest soils have a BC:Al ratio close to 1.0 in contrast to the higher ratio of the

389 young forest soils. The vegetation, both understory and canopy, of the uncut forest are adapted to low

$390 \mathrm{pH}$ conditions, as well as a low cation aluminum ratios. Soil solution BC:Al ratios less than 1.0 has been

391 suggested possible root damage and stress for some tree species (Cronan and Grigal, 1995; Sverdrup et

392 al., 1996). However, in general, there is little evidence to support that low BC:Al ratios are indicators of

393 potential stress in forest ecosystems (e.g., Wargo et al., 2003). Soil fertility can be maintained across a

394 range of cationic ratios; in other words, there is no ideal basic cation saturation ratio or range (Eckert,

395 1987; Eckert and McLean, 1981; Kopittke and Menzies, 2007). 


\subsection{Organisms}

The amount, diversity and type of litter determine the annual organic carbon input into temperate deciduous forests. Soil fauna is the driver that connects, integrates, and mixes above- and below-ground parts of the ecosystem and earthworms are a keystone group in this process (De Deyn and Van der

402 Putten, 2005; Wardle et al., 2004). Although not directly included in the present study, we have 403 sampled earthworm abundance and activity in many SERC forests stands, including the sites reported 404 here. In general, earthworms are abundant in the secondary forest stands, but are absent on the uncut 405 stands. The species composition and biomass of the earthworm communities differ between old and 406 young stands, even though there is temporal variation at each site that has earthworms (Szlavecz and 407 Csuzdi, 2007; Szlavecz et al., 2011). Non-native earthworms may have been established after the 408 creation of agriculture fields. Most species are common both in forests and in open habitats, including 409 arable fields. The earthworms most likely remained in the recovering forests. Altered carbon chemistry 410 and storage due to selective feeding has been attributed to earthworms (Filley et al., 2008) and has a 411 lasting legacy in the soil (Crow et al., 2009; Ma et al., 2013). Earthworms can indirectly affect understory

412 plants as has been shown for orchids at SERC (McCormick et al., 2013), ferns in Minnesota (Gundale, 413 2002), eventually modifying the structure and function of the entire plant community (Forey et al., 2011; 414 Hale et al., 2006; Nuzzo et al., 2009).

415 One of the greatest differences among stands that could be related to historical events was soil 416 organic matter content, which was highly related to the presence or absence of $\mathrm{O}$ horizons. In the uncut 417 forest soil, the $\mathrm{O}$ horizon mass averaged $3.6 \pm 0.6 \mathrm{~kg} \mathrm{~m}^{-2}$, whereas in the old forest soils, there was no 418 measurable $\mathrm{O}$ horizon (Table 2). The $\mathrm{O}$ horizon contributes a significant amount of $\mathrm{C}$ and was the reason 419 that uncut forest soils had a higher $\mathrm{C}$ content in the surface depth, which included the $\mathrm{O}$ horizon and the 
421 of temperate forest soils (Davidson and Ackerman, 1993; Johnson, 1992) which was similar to the

422 reduction of $32 \%$ from the uncut to the old carbon content in SERC soils. The disappearance of the $\mathrm{O}$

423 layer was also the most visible effect of non-native earthworm activity (Alban and Berry, 1994;

424 Eisenhauer et al., 2007; Fahey et al., 2013). Regardless of the reason of the original loss of O layer, the C 425 content had not increased after 75 years of succession, i.e., from the young versus old forest stands,

426 which was similar for carbon content in the plow layer 10-115 years after agricultural abandonment for 427 a Rhode Island forest (Hooker and Compton, 2003). On a subset of our sampling sites, Ma et al. (2013)

428 has shown distinct differences among soil carbon aggregate fractions and attributed these to past land 429 use in combination with earthworm presence. In Belgium, Muys et al. (1992) showed that as long as 430 palatable leaf litter was available, earthworms prevented the development of organic layer and moder 431 humus during afforestation. Additionally, bioturbation magnifies the nutrient concentration difference 432 between the old and uncut surface layers because the nutrient rich $\mathrm{O}$ horizon is incorporated into the 433 old forest soil's $0-10 \mathrm{~cm}$ layer in contrast to the uncut forest soil. While agricultural legacies are still 434 detected in old forest soils, present nutrient concentrations may be more strongly affected by the 435 ongoing mixing of leaf litter with mineral soil. Detailed chemical analyses of plant litter residue and 436 different fractions of soil organic matter at a subset of our sites strongly support the latter mechanism 437 (Filley et al., 2008; Crow et al., 2008; Ma et al. 2013).

\subsection{Forest soil trajectory}

Time was central to this study, as our questions address soil recovery after agricultural

442 abandonment and as forests age. When and if a forest recovers in either function or form is subject to 443 interpretation but once a forest is disturbed, a new trajectory is created and this new trajectory affects 
444 future composition and structure both for vegetation and soils (Cramer et al., 2008; Foster et al., 2003;

445 Huggett, 1998) and soil biota. Some soil properties, such as carbon content may return to pre-

446 disturbance levels. However vertical distribution in the soil profile and proportion of $\mathrm{C}$ in different

447 aggregate fractions (Ma et al 2013) may be modified; both can affect microbial activity and thus nutrient

448 availability. Biotic properties, such as vegetation and soil biota, could recover in biomass but not in

449 species composition. For instance, total annual leaf litter input is similar in the uncut and old forests at

450 SERC (Szlavecz unpublished), but composition of litter is different (Table 1). Litter chemistry of a forest

451 composed of mostly Tulip poplar and red maple affect soil properties differently than one dominated by

452 species of oak. Also, forest soil without non-native earthworms could shift to one with abundant

453 earthworms as is the case at SERC. These confounding factors may drive the trajectory of the ecosystem,

454 including the soil subsystem to an alternative stable state.

455

456 5. Conclusions

457

Quantifying and separating the effects of past history and forest stand age on soil characteristics is challenging. The chemical and physical factors that were important in showing an age effect between young forest and old forest soils at $\mathrm{SERC}$ were $\mathrm{pH}, \mathrm{Ca}, \mathrm{Mg}$, and $\mathrm{NO}_{3}$, which may be related to

461 weathering, leaf litter quality inputs, and agricultural inputs such as manure, marl, and gypsum.

462 Evidence of a historical land-use legacy, the soils of the uncut forest stands had an $\mathrm{O}$ horizon that was 463 not found in the young and old forest soils, and a lower bulk density. The surface horizon differences 464 were affected by agriculture practices and inputs due to cultivation, to the foot and equipment traffic 465 related to sowing and harvesting, erosion due to clearing and logging, mixing caused by introduced 466 organisms, e.g. earthworms, and nutrient-rich leaf litter quality input. The Bt horizon was generally 467 closer to the surface in the young forest soils which we interpret as an indication of erosion during the 
time that the stands were used for agricultural practices. Given our results, we predict that the young

469 forest soil will become more like the old forest soil with a decrease in $\mathrm{pH}$, loss of nitrate and cations such

470 as $\mathrm{Ca}$ and $\mathrm{Mg}$; along with a corresponding increase in Al. We believe that the results of this study, which

471 were conducted in a restricted area to reduce variability, can be generalized to a larger area especially in

472 the Chesapeake Bay region with similar land-use history and current vegetation, such as the Tulip poplar 473 association (Brush et al., 1980).

$474 \quad$ Anthropogenic influences may keep forest ecosystems and their soils evolving, and create different

475 and permanent trajectories which will affect forest soils irreversibly. McMahon et al. (2010) showed that

476 the growth rate of trees at SERC has recently increased presumably due to $\mathrm{CO}_{2}$ fertilization. Additionally,

477 climate models project increased frequency and intensity of precipitation for the Mid-Atlantic region

478 (Meehl et al., 2005) that may profoundly affect carbon cycling both above- and belowground. Increasing

479 human population on the region leads to increased $\mathrm{N}$-deposition and new species introduction. As an

480 example, in one of our old forest stands, Treefall, several Asian earthworm species are currently

481 invading from the neighboring residential areas (Chang et al., 2016). These future influences will cause

482 trajectories of forest soils to diverge further away from the pre-Colonial states even affecting those

483 forests that have not been cut or managed previously.

484

485 Acknowledgements

486 This study was partially supported by grants from the United States Department of Agriculture

487 (USDA-CSREES NRI 2007-35320-18375) and the National Science Foundation (EEC-0540832 ERC-

488 MIRTHE). We thank Nancy Goff (SERC Nutrient Lab), Jay O’Neill (SERC Plant Ecology Lab), Emma Powell

489 (USDA Forest Service), and Dean Cowherd (NRCS) for their help in various stages in the laboratory and in 490 the field.

491 
493 Figure 1. The general history of the uncut, old, and young forest soils and the comparisons between land

494 use and age, i.e., for land-use comparisons, uncut was compared to old and young forest soil; for age

495 comparisons, old was compared to young forest soils. The evolution of these soils is affected by

496 pedogenic processes.

497

498 Figure 2. Map of site locations within the Smithsonian Environmental Research Center in Edgewood,

499 Maryland.

500

501 Figure 3. The depth of the top of the Bt horizon versus clay percentage. Mean \pm std err, $n=9$ for each

502 site. Not all forest stands were sampled for depth of Bt horizon.

503

504 Figure 4. Principal component analysis. Figure $A$ is the surface depth at $0-10 \mathrm{~cm}$ and Figure $B$ is the lower 505 soil depth at $10-20 \mathrm{~cm}$.

506

507 Figure 5. The soil pH versus base cation aluminum ratios. For the surface soil depth, Hog Island and Big

508 Island are both pH 4.2. For the lower soil depth, Frog Canyon, Weir, and Fox Point all have a pH of 4.7.

509 Figure $A$ is the surface depth at $0-10 \mathrm{~cm}$ and Figure $B$ is the lower soil depth at $10-20 \mathrm{~cm}$.

510

511 References:

512 Alban, D.H., Berry, E.C., 1994. Effects of earthworm invasion on morphology, carbon, and 513 nitrogen of a forest soil. Applied Soil Ecology 1, 243-249.

Bellemare, J., Motzkin, G., Foster, D.R., 2002. Legacies of the agricultural past in the forested 515 present: an assessment of historical land-use effects on rich mesic forests. J Biogeogr 29, 1401-1420. 
Besley, F.W., 1916. The forests of Maryland. Maryland State Board of Forestry, Baltimore.

Bigelow, S.W., Canham, C.D., 2002. Community organization of tree species along soil gradients in a north-eastern USA forest. Journal of Ecology 90, 188-200.

Blake, G.R., Hartge, K.H., 1986. Bulk Density, in: Klute, A. (Ed.), Methods of soil analysis, Part 1. Physical and mineralogical methods. American Society of Agronomy - Soil Science Society of America, Madison, WI, pp. 363-375.

Blouin, M., Hodson, M.E., Delgado, E.A., Baker, G., Brussaard, L., Butt, K.R., Dai, J., Dendooven, L., Peres, G., Tondoh, J.E., Cluzeau, D., Brun, J.-J., 2013. A review of earthworm impact on soil function and ecosystem services. Eur J Soil Sci 64, 161-182.

Brunet, J., De Frenne, P., Holmstrom, E., Mayr, M.L., 2012. Life-history traits explain rapid colonization of young post-agricultural forests by understory herbs. Forest Ecology and Management $278,55-62$.

Brush, G.S., 1986. Geology and paleoecology of Chesapeake Bay: a long-term monitoring tool for management. Journal of the Washington Academy of Sciences 76, 146-160.

Brush, G.S., C., L., Smith, J., 1980. The natural forests of Maryland: An explanation of the vegetation map of Maryland. Ecological Monographs 50, 77-92.

Burtelow, A., Bohlen, P.J., Groffman, P.M., 1998. Influence of exotic earthworm invasion on soil organic matter, microbial biomass and denitrification potential in forest soils of the northeastern United States. Applied Soil Ecology 9, 197-202.

Chang, C.H., Szlavecz, K., Filley, T., Buyer, J., Bernard, M., Pitz, S., 2016. Belowground competition among invading detritivores. Ecology 97: 160-170.

Compton, J.E., Boone, R.D., 2000. Long-term impacts of agriculture on soil carbon and nitrogen in New England forests. Ecology 81, 2314-2330.

Cook-Patton, S.C., Weller, D., Rick, T.C., Parker, J.D., 2014. Ancient experiments: forest biodiversity and soil nutrients enhanced by Native American middens. Landscape Ecology 29, 979-987.

Cooper, S.R., 1995. Chesapeake Bay watershed historical land-use - Impact on water-quality and diatom communities. Ecological Applications 5, 703-723. 
Correll, D.L., 1974. Envionmental monitoring and baseline data, temperate studies, Volume 3, Rhode River, Maryland, Smithsonian Institute Environmental Sciences Program.

Coudun, C., Gegout, J.C., Piedallu, C., Rameau, J.C., 2006. Soil nutritional factors improve models of plant species distribution: an illustration with Acer campestre (L.) in France. J Biogeogr 33, 1750-1763.

Cramer, V.A., Hobbs, R.J., Standish, R.J., 2008. What's new about old fileds? Land abandonment and ecosystem assembly. Trends In Ecology \& Evolution 23, 104-112.

Cronan, C.S., Grigal, D.F., 1995. Use of calcium aluminum ratios as indicators of stress in forest ecosystems. Journal of Environmental Quality 24, 209-226.

Cronon, W., 1983. Changes in the land. Indians, colonists, and the ecology of New England. Douglas and Mclntyre Ltd.

Crow, S.E., Filley, T.R., McCormick, M., Szlavecz, K., Stott, D.E., Gamblin, D., Conyers, G., 2009. Earthworms, stand age, and species composition interact to influence particulate organic matter chemistry during forest succession. Biogeochemistry 92, 61-82.

Davidson, E.A., Ackerman, I.L., 1993. Changes in soil carbon inventories following cultivation of previously untilled soils. . Biogeochemistry 20, 161-193.

De Deyn, G.D., Van der Putten, W., 2005. Linking aboveground and belowground diversity. Trends In Ecology \& Evolution 20, 625-633.

DeGryze, S., Six, J., Paustian, K., Morris, S.J., Paul, E.A., Merck, R., 2004. Soil organic carbon pool changes following land-use conversions. Global Change Biology 10, 1120-1132.

Dupouey, J.L., Dambrine, E., Laffite, J.D., Moares, C., 2002. Irreversible impact of past land use on forest soils and biodiversity. Ecology 83, 2978-2984.

Eckert, D.J., 1987. Soil test interpretations: Basic cation saturation ratios and sufficiency levels., in: Brown, J.R. (Ed.), Soil testing: Sampling, correlation, calibration, and interpretation. SSSA Spec. Publ. , SSSA, Madison, WI., pp. 53-64.

Eckert, D.J., McLean, J., 1981. Basic cation saturation ratios as a basis for fertilizing and liming agronomic crops: I. Growth chamber studies. Agron. J., 795-799. 
Eisenhauer, N., Partsch, S., Parkinson, D., Scheu, S., 2007. Invasion of a deciduous forest by earthworms: changes in soil chemistry, microflora, microarthropods and vegetation. Soil Biol. Biochem. 39, 1099-1110.

Fahey, T.J., Yavitt, J.B., Sherman, R.E., Maerz, J.C., Groffman, P.M., Fisk, M.C., Bohlen, P.J., 2013. Earthworms, litter and soil carbon in a northern hardwood forest. Biogeochemistry 114, 269-280.

Falkengren-Grerup, U., ten Brink, D., Brunet, J., 2006. Land use effects on soil N, P, C and pH persist over 40-80 years of forest growth on agricultural soils. Forest Ecology and Management 225, 7481.

Fanning, D.S., Fanning, M.C.B., 1989. Soil morphology, genesis, and classification. John Wiley and Sons, New York.

Filley, T., McCormick, M., Crow, S., Szlavecz, K., Whigham, D., Taylor, D., Johnston, C., van den Heuvel, R., 2008. Comparison of the chemical alteration trajectory of Liriodendron tulipifera L. leaf litter among forests with different earthworm abundance. Journal of Geophysical Research 113.

Flinn, K.M., P.L. Marks, 2007. Agricultural legacies in forest environments: tree communities, soil properites, and light availability. Ecological Applications 17, 452-463.

Forey, E., Barot, S., Decaens, T., Langlois, E., Laossi, K.R., Margerie, P., Scheud, S., Eisenhauere, N., 2011. Importance of earthworm-seed interactions for the composition and structure of plant communities: A review. Acta Oecol 37, 594-603.

Foster, D., Aber, J., 2003. Forest in time, the environmental consequences of 1000 years of change in New England. Yale University Press, New Haven.

Foster, D., Swanson, F., Aber, J., Burke, I., Brokaw, N., Tilman, D., Knapp, A., 2003. The importance of land-use legacies to ecology and conservation. BioScience 53, 77-88.

Franzluebbers, A.J., Stuedemann, J.A., 2013. Soil-profile distribution of inorganic N during 6 years of integrated crop-livestock management. Soil Till Res 134, 83-89.

Fraterrigo, J.M., Turner, M.G., Pearson, S.M., Dixon, P., 2005. Effects of past land use on spatial heterogeneity of soil nutrients in Southern Appalachian forests. Ecological Monographs 75, 215-230.

Gundale, M.J., 2002. Influence of exotic earthworms on the soil organic horizon and the rare fern Botrychium mormo. Conservation Biology 16, 1555-1561. 
Hale, C.M., Frelich, L.E., Reich, P.B., 2006. Changes in hardwood forest understory plant communities in response to European earthworm invasions. Ecology 87, 1637-1649.

Hale, C.M., Frelich, L.E., Reich, P.B., Pastor, J., 2005. Effects of European earthworm invasion on soil characteristics in northern hardwood forests of Minnesota, USA. Ecosystems 8, 911-927.

Higman, D., 1968. An ecologically annotated checklist of the vascular flora at the Chesapeake Bay center for field biology, with keys. Office of Ecology Smithsonian Institution, Washington, D.C.

Honnay, O., Hermy, M., Coppin, P., 1999. Impact of habitat quality on forest plant species colonization. Forest Ecology and Management 115, 157-170.

Hooker, T.D., Compton, J.E., 2003. Forest ecosystem carbon and nitrogen accumulation during the first century after agricultural abandonment. Ecological Applications 13, 299-313.

Huggett, R.J., 1998. Soil chronosequences, soil development, and soil evolution: a critical review. Catena 32, 155-172.

Java Dairy Farm, n.d. in Smithsonian Environmental Research Center, Retrieved 10/6/2015 from http://serc.si.edu/education/programs/iava/guide/java dairy.aspx

Jenkins, D.W., Higman, D., Weck, S.,. 1971. Collection and analysis of remotely sensed data from the Rhode river estuary watershed. 2nd Progress report. Chesapeake Bay Center for Environmental Studies. Smithsonian Institution.

Jenny, H., 1941. Factors of soil formation. McGraw-Hill, New York.

Johnson, D.W., 1992. Effects of forest management on soil carbon storage. Water Air And Soil Pollution 64, 83-120.

Johnson, E.A., Miyanishi, K., 2008. Testing the assumptions of chronosequences in succession. Ecology Letters 11, 419-431.

Koerner, W., Dupouey, J.L., Dambrine, E., Benoit, M., 1997. Influence of past land use on the vegetation and soils of present day forest in the Vosges mountains, France. Journal of Ecology 85, 351358. 
Kopittke, P.M., Menzies, N.W., 2007. A review of the use of the basic cation saturation ratio and the "ideal" soil. Soil Science Society of America Journal 71, 259-265.

Lyon, T.L., Buckman, H.O., Brady N.C., 1952. The nature and properties of soils, 5th Edition. New York: Macmillan.

Ma, Y., Filley, T.R., Johnston, C.T., Crow, S.E., Szlavecz, K., McCormick, M.K., 2013. The combined controls of land use legacy and earthworm activity on soil organic matter chemistry and particle association during afforestation. Org Geochem 58, 56-68.

McCormick, M.K., Parker, K.L., Szlavecz, K., Whigham, D.F., 2013. Native and exotic earthworms affect orchid seed loss. Aob Plants 5.

McMahon, S.M., Parker, G.G., Miller, D.R., 2010. Evidence for a recent increase in forest growth. P Natl Acad Sci USA 107, 3611-3615.

Meehl, G.A., Arblaster, J.M., Tebaldi, C., 2005. Understanding future patterns of increased precipitation intensity in climate model simulations. Geophysical Research Letters 32.

Mudrick, D.A., Hoosein, M., Hicks, R.R., Townsend, E.C., 1994. Decomposition of leaflitter in an Appalachian forest - Effects of leaf species, aspect, Slope position and time. Forest Ecology and Management 68, 231-250.

Muys, B., Lust, N., Granval, P., 1992. Effects of grassland afforestation with different tree species on earthworm communities, litter decomposition and nutrient status. Soil Biology \& Biochemistry 24, 1459-1466.

NRCS, 2005, Nov 30. Soil Survey Staff, Natural Resources Conservation Service, United States Department of Agriculture. Official soil series descriptions. https://soilseries.sc.egov.usda.gov/osdname.asp accessed 11/18/2015.

NRCS, 2015, Dec 1. Soil Survey Staff, Natural Resources Conservation Service, United States Department of Agriculture. Web Soil Survey. http://websoilsurvey.nrcs.usda.gov/ accessed 11/19/2015.

Nuzzo, V.A., Maerz, J.C., Blossey, B., 2009. Earthworm invasion as the driving force behind plant Invasion and community change in Northeastern North American forests. Conservation Biology 23, 966974. 
Ouimet, R., Moore, J.D., Duchesne, L., 2013. Soil thresholds update for diagnosing foliar calcium, potassium, or phosphorus deficiency of sugar maple. Communications In Soil Science And Plant Analysis $44,2408-2427$.

Parker, John D., Richie, Lauren J., Lind, Eric and Maloney, Kelly O., 2010. Land use history alters the relationship between native and exotic plants: the rich don't always get richer. Biological Invasions, 12(6): 1557-1571.

Pickett, S.T.A., 1989. Space-for-time substitution as an alternative to long-term studies, in: Likens, G.E. (Ed.), Long-term studies in ecology: Approaches and alternatives, Part I. Springer New York, New York, pp. 110-135.

Pierce, J.W., 1974. Geology and soils of the Rhode river watershed.

Reganold, J.P., Elliottt, L.F., Unger, Y.L., 1987. Long-term effects of organic and conventional farming on soil erosion. Nature 330, 370-372.

SAS, 2010. The SAS system for Windows. Release 9.13. Cary, NC: SAS Inst.

Schrijver, A.D., Vesterdal, L., Hansen, K., Frenne, P.D., Augusto, L., Achat, D.L., Staelens, J., Baeten, L., Keersmaeker, L.D., Neve, S.D., Verheyen, K., 2012. Four decades of post-agricultural forest development have caused major redistributions of soil phosphorus fractions. Oecologia 169, 221-234.

Stolte, K., Conkling, B., Fulton, S., Bradley, P., 2012. State of Mid-Atlantic region forests in 2000. United States Department of Agriculture Forest Service GTR SRS-162.

Sverdrup, H., Warfvinge, P., Britt, D., 1996. Assessing the potential for forest effects due to soil acidification in Maryland. Water Air And Soil Pollution 87, 245-265.

Switzer, G.L., Shelton, M.G., Nelson, L.E., 1979. Successional development of the forest floor and soil surface on upland sites of the East Gulf Coastal-Plain. Ecology 60, 1162-1171.

Szlavecz, K., Csuzdi, C., 2007. Land use change affects earthworm communities in Eastern Maryland, USA. European Journal Of Soil Biology 43, S79-S85.

Szlavecz, K., McCormick, M., Xia, L., Saunders, J., Morcol, T., Whigham, D., Filley, T., Csuzdi, C., 2011. Ecosystem effects of non-native earthworms in Mid-Atlantic deciduous forests. Biological Invasions 13, 1165-1182. 
676

677

678

679

680

681

682

683

684

685

686

687

688

689

690

691
Szlavecz, K., Placella, S.A., Pouyat, R.V., Groffman, P.M., Csuzdi, C., Yesilonis, I., 2006. Invasive earthworm species and nitrogen cycling in remnant forest patches. Applied Soil Ecology 32, 54-62.

Thompson, J.R., Carpenter, D.N., Cogbill, C.V., Foster, D.R., 2013. Four centuries of change in Northeastern United States forests. Plos ONE 8.

Tiessen, H., Stewart, J.W.B., Bettany, J.R., 1982. Cultivation effects on the amounts and concentration of carbon, nitrogen, and phosphorus in grassland soils. Agronomy Journal 74, 831-835.

Verheyen, K., Bossuyt, B., Hermy, M., Tack, G., 1999. The land use history (1278-1990) of a mixed hardwood forest in western Belgium and its relationship with chemical soil characteristics. J Biogeogr 26, 1115-1128.

Wardle, D.A., Bardgett, R.D., Klironomos, J.N., Setala, H., van der Putten, W.H., Wall, D.H., 2004. Ecological linkages between aboveground and belowground biota. Science 304, 1629-1633.

Wargo, P.M., Vogt, K., Vogt, D., Holifield, Q., Tilley, J., Lawrence, G., David, M., 2003. Vitality and chemistry of roots of red spruce in forest floors of stands with a gradient of soil Al/Ca ratios in the northeastern United States. Can J Forest Res 33, 635-652.

Wilde, S.A., Voigt, G.K., Iyer, J.C., 1972. Soil and plant analysis for tree culture. Oxford and IBH Publishing Co., New Delhi, India. 
Table 1. Historical land use, vegetation and soil type for 13 forest stands at the Smithsonian Environmental Research Center. More information on sites and soil is given in the Methods and in Supplement A.

\begin{tabular}{|c|c|c|c|c|c|c|}
\hline \multirow{2}{*}{ Age of stand } & \multirow{2}{*}{ Site name } & \multicolumn{3}{|c|}{ Vegetation - Land use maps ${ }^{1}$} & \multirow{2}{*}{ Soil $^{2}$} & \multirow[b]{2}{*}{ Tree leaf litter $^{3}$} \\
\hline & & 1846 & $1925-45$ & 1965 & & \\
\hline \multirow{4}{*}{$\begin{array}{c}\text { Young } \\
50-70 \text { years }\end{array}$} & Front Gate & Improved land & $\begin{array}{c}\text { Barley/Wheat/Corn } \\
\text { or Orchard }\end{array}$ & Sweetgum & Donlonton & $\begin{array}{c}\text { Tulip poplar, Maple, } \\
\text { Sweetgum }\end{array}$ \\
\hline & $\begin{array}{l}\text { Fox Point } \\
\text { Road }\end{array}$ & Improved land & Corn/Alfalfa & $\begin{array}{c}\text { Regenerating forest } \\
\text { and pasture } \\
\text { (Rubus/Lonicera/Rhus ) }\end{array}$ & Annapolis & $\begin{array}{l}\text { Tulip poplar, } \\
\text { Sweetgum }\end{array}$ \\
\hline & Canoe Shed & Improved land & Corn/Alfalfa & $\begin{array}{c}\text { Regenerating forest } \\
\text { and pasture } \\
\text { (Rubus/Lonicera/Rhus) }\end{array}$ & Annapolis & Tulip poplar \\
\hline & $\begin{array}{l}\text { Education } \\
\text { Center }\end{array}$ & Improved land & Alfalfa & $\begin{array}{l}\text { Regenerating forest and } \\
\text { pasture (Solidago-Aster) }\end{array}$ & Annapolis & $\begin{array}{l}\text { Sweetgum, Tulip } \\
\text { poplar }\end{array}$ \\
\hline \multirow{4}{*}{$\begin{array}{c}\text { Old } \\
120-150 \\
\text { years }\end{array}$} & Tower & Woodland & Forest & Hardwoods & Adelphia/Holmdel & $\begin{array}{c}\text { Tulip poplar, Beech, } \\
\text { Sweetgum }\end{array}$ \\
\hline & Frog Canyon & Improved land & Forest & Hardwoods & Annapolis & $\begin{array}{c}\text { Tulip poplar, Maple, } \\
\text { Oak }\end{array}$ \\
\hline & Weir & Woodland & Forest & Hardwoods & Annapolis & $\begin{array}{c}\text { Beech, Tulip poplar, } \\
\text { Oak }\end{array}$ \\
\hline & Triangle & Woodland & Forest & Hardwoods & Collington/Annapolis & $\begin{array}{c}\text { Tulip poplar, Beech, } \\
\text { Sweetgum }\end{array}$ \\
\hline
\end{tabular}




\begin{tabular}{|c|c|c|c|c|c|c|}
\hline & Treefall & Woodland $^{5}$ & Forest & Hardwoods & Collington/Annapolis & $\begin{array}{c}\text { Tulip poplar, Beech, } \\
\text { Oak }\end{array}$ \\
\hline \multirow[t]{2}{*}{$\begin{array}{c}\text { Uncut } \\
>200 \text { years }\end{array}$} & Big Island & Woodland & Forest & Hardwoods & Collington/Annapolis & Oak \\
\hline & Hog Island & Woodland & Forest & Hardwoods & Donlonton & Oak \\
\hline
\end{tabular}

${ }^{1}$ Sources of maps: US Coast Guard and Geodetic Surveys (Higman, 1968; Higman, unpublished; Correll, 1974)

${ }^{2}$ NRCS, Soil Survey Staff, Natural Resources Conservation Service, United States Department of Agriculture. Web Soil Survey. http://websoilsurvey.nrcs.usda.gov/ accessed $11 / 19 / 2015$

${ }^{3}$ Leaf litter was collected using six $20 \mathrm{~L}$ buckets per site between September-December 2010, and sorted to major types.

${ }^{4}$ This term was used in map and possibly means agriculture. All terms in the table were taken from the original maps.

${ }^{5}$ This site was outside of the 1846 map boundary. Vegetation was inferred from the neighboring forest areas and written history (Higman, 1968) 
Table 2. Physical and chemical soil properties in 13 forest stands at the Smithsonian Environmental Research Center. Mean values and standard error (in parentheses) are given. Significant differences (Proc MIXED) among the forest stands are in boldface. Different letters indicate significant differences between forest stands at $P<0.05$. Carbon content includes $O$ layer in the uncut stands

\begin{tabular}{|c|c|c|c|c|c|}
\hline \multirow[b]{2}{*}{ Physical properties } & \multirow[b]{2}{*}{ Depth (cm) } & \multirow[t]{2}{*}{ Young (n=5) } & \multirow[t]{2}{*}{ Old $(n=5)$} & \multirow[t]{2}{*}{ Uncut $(n=3)$} & \multirow[t]{2}{*}{$P$ value } \\
\hline & & & & & \\
\hline O layer mass $\left(\mathrm{kg} \mathrm{m}^{-2}\right)$ & & $\mathrm{n} / \mathrm{a}$ & $\mathrm{n} / \mathrm{a}$ & $3.6(0.6)$ & $\mathrm{n} / \mathrm{a}$ \\
\hline Bulk density $\left(\mathrm{g} \mathrm{cm}^{-3}\right)$ & $0-5$ & $1.00(0.05)^{\mathrm{a}}$ & $0.82(0.06)^{a}$ & $0.43(0.08)^{b}$ & 0.0009 \\
\hline Depth to $\mathrm{Bt}(\mathrm{cm})$ & & $18(3.7)^{\mathrm{a}}$ & $25(2.0)^{a b}$ & $40(2.0)^{b}$ & 0.012 \\
\hline \multirow[t]{2}{*}{ Clay (\%) } & $0-10$ & $19(1.1)$ & $19(2.1)$ & $15.0(0.69)$ & 0.30 \\
\hline & $10-20$ & $23(1.5)$ & $24(3.6)$ & $17(2.0)$ & 0.30 \\
\hline \multirow[t]{2}{*}{ Sand (\%) } & $0-10$ & $48(2.7)$ & $52(2.9)$ & $46(8.5)$ & 0.63 \\
\hline & $10-20$ & $46(2.3)$ & 47 (4.9) & $45(6.1)$ & 0.97 \\
\hline \multirow[t]{2}{*}{ Silt (\%) } & $0-10$ & $34(3.1)$ & $32(0.74)$ & $40(7.7)$ & 0.47 \\
\hline & $10-20$ & $31(3.2)$ & $34(2.5)$ & $39(4.0)$ & 0.38 \\
\hline \multicolumn{6}{|l|}{ Chemical properties } \\
\hline$C$ content $\left(\mathrm{kg} \mathrm{m}^{-2}\right)$ & & $2.6(0.29)^{\mathrm{ab}}$ & $2.31(0.07)^{a}$ & $3.4(0.22)^{b}$ & 0.025 \\
\hline O layer organic matter content (\%) & & $\mathrm{n} / \mathrm{a}$ & $\mathrm{n} / \mathrm{a}$ & $65.0(4.78)$ & $\mathrm{n} / \mathrm{a}$ \\
\hline \multirow[t]{2}{*}{ C (mineral layer, \%) } & $0-10$ & $2.6(0.21)^{a}$ & $2.8(0.10)^{\mathrm{ab}}$ & $4.2(0.69)^{b}$ & 0.017 \\
\hline & $10-20$ & $0.93(0.02)$ & $1.2(0.26)$ & $1.4(0.40)$ & 0.27 \\
\hline \multirow[t]{2}{*}{$\mathrm{N}(\%)$} & $0-10$ & $0.22(0.03)$ & $0.17(0.019)$ & $0.17(0.035)$ & 0.34 \\
\hline & $10-20$ & $0.09(0.01)$ & $0.08(0.02)$ & $0.06(0.05)$ & 0.67 \\
\hline C:N & $0-10$ & $12.2(0.79)^{\mathrm{a}}$ & $17(2.0)^{\mathrm{ab}}$ & $25.1(1.5)^{b}$ & 0.0011 \\
\hline
\end{tabular}




\begin{tabular}{|c|c|c|c|c|c|}
\hline & $10-20$ & $10.9(0.99)$ & $27(13)$ & 70 (55) & 0.26 \\
\hline \multirow[t]{2}{*}{ pH } & $0-10$ & $5.4(0.16)^{b}$ & $4.9(0.23)^{\mathrm{a}}$ & $4.17(0.03)^{\mathrm{a}}$ & 0.0009 \\
\hline & $10-20$ & $4.8(0.12)$ & $4.7(0.19)$ & $4.6(0.18)$ & 0.050 \\
\hline \multirow[t]{2}{*}{$\mathrm{Ca}\left(\mathrm{mg} \mathrm{kg}^{-1}\right)$} & $0-10$ & $2400(280)^{b}$ & $700(180)^{\mathrm{a}}$ & $50(12)^{\mathrm{a}}$ & $<0.0001$ \\
\hline & $10-20$ & $1600(290)^{\mathrm{b}}$ & $160(56)^{\mathrm{a}}$ & $23(8.8)^{\mathrm{a}}$ & 0.0003 \\
\hline \multirow[t]{2}{*}{$\mathrm{Mg}\left(\mathrm{mg} \mathrm{kg}^{-1}\right)$} & $0-10$ & $470(49)^{b}$ & $220(66)^{\mathrm{a}}$ & $60(10)^{\mathrm{a}}$ & 0.0017 \\
\hline & $10-20$ & $360(55)^{b}$ & $90(46)^{\mathrm{a}}$ & $27(4.4)^{\mathrm{a}}$ & 0.0016 \\
\hline \multirow[t]{2}{*}{$\mathrm{Al}\left(\mathrm{mg} \mathrm{kg}^{-1}\right)$} & $0-10$ & $80(10)^{b}$ & $300(63)^{\mathrm{ab}}$ & $500(120)^{\mathrm{a}}$ & 0.0038 \\
\hline & $10-20$ & $210(31)^{\mathrm{a}}$ & $500(120)^{\mathrm{ab}}$ & $700(140)^{b}$ & 0.020 \\
\hline \multirow[t]{2}{*}{$P\left(\mathrm{mg} \mathrm{kg}^{-1}\right)$} & $0-10$ & $3(1.5)$ & $3.3(0.84)$ & $7(2.7)$ & 0.24 \\
\hline & $10-20$ & $1.0(1.0)$ & $4.2(0.73)$ & $9(5.9)$ & 0.11 \\
\hline \multirow[t]{2}{*}{$\mathrm{K}\left(\mathrm{mg} \mathrm{kg}^{-1}\right)$} & $0-10$ & 250 (19) & $210(28)$ & $170(49)$ & 0.21 \\
\hline & $10-20$ & $160(11)$ & 110 (18) & $100(22)$ & 0.067 \\
\hline \multirow[t]{2}{*}{$\mathrm{NO}_{3}\left(\mathrm{mg} \mathrm{kg}^{-1}\right)$} & $0-10$ & $50(7.4)^{\mathrm{b}}$ & $7(7)^{a}$ & ${ }^{*}$ bdl ${ }^{a}$ & 0.0004 \\
\hline & $10-20$ & bdl & bdl & bdl & $n / a$ \\
\hline \multirow[t]{2}{*}{ BC:Al } & $0-10$ & $43(9.0)^{b}$ & $4(1.1)^{a}$ & $0.58(0.037)^{\mathrm{a}}$ & 0.0010 \\
\hline & $10-20$ & $12(3.7)^{\mathrm{b}}$ & $0.74(0.14)^{\mathrm{a}}$ & $0.23(0.020)^{\mathrm{a}}$ & 0.0113 \\
\hline
\end{tabular}

*Below detection level

Texture analysis in the "Uncut" was carried out for two sites.

Depth of Bt was determined for four "Young", three "Old", and two "Uncut" sites.

$\mathrm{Ca}, \mathrm{Mg}, \mathrm{Al}, \mathrm{P}, \mathrm{K}$ and $\mathrm{NO}_{3}$ are Morgan extractable concentrations. $\mathrm{BC}$ : Base cations 


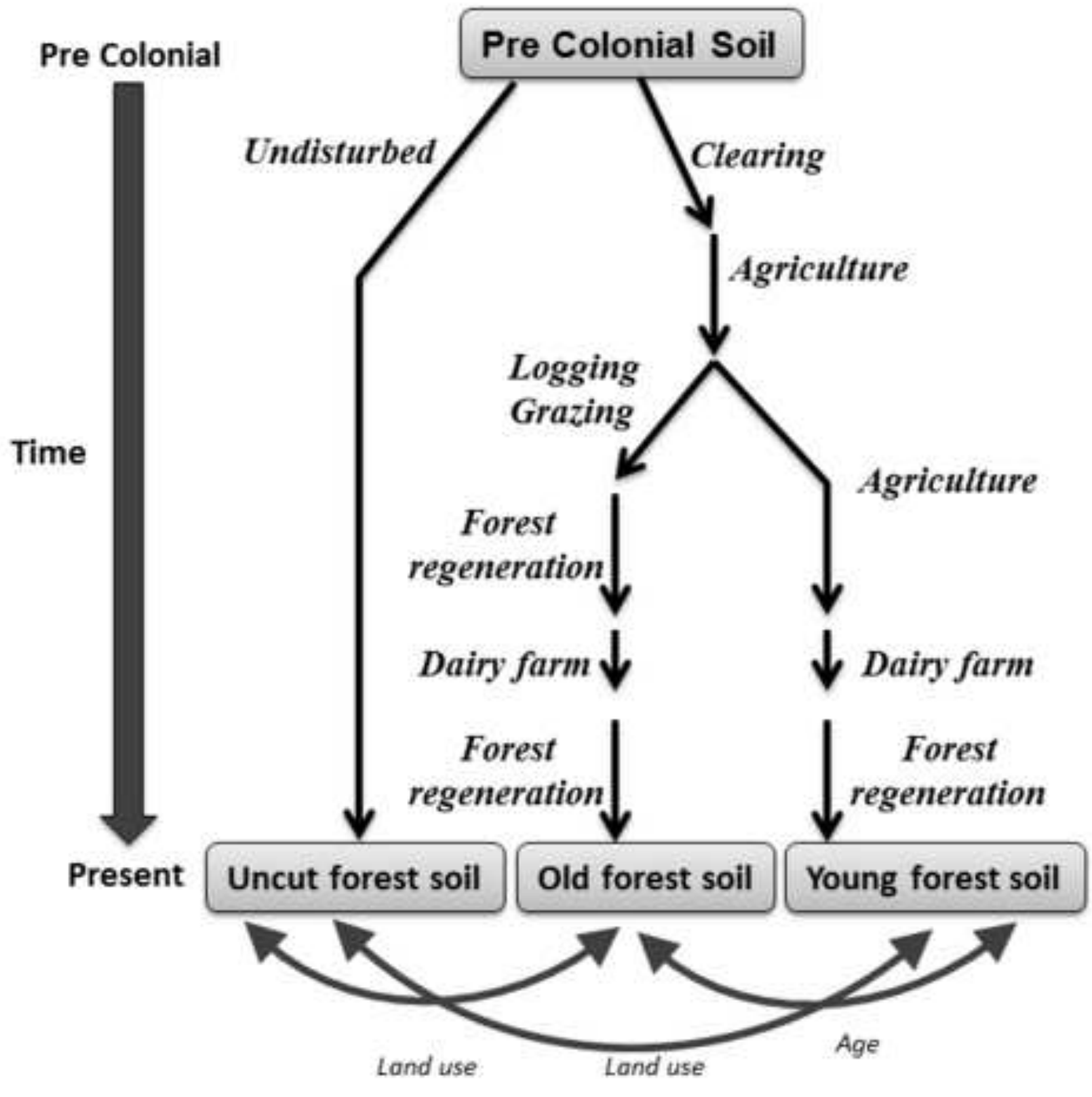

Pedogenic processes

Erosion of $\mathrm{O}$ horizon

Amendments

Mixing of soil

Compaction

Erosion

Litter quality and quantity Exotic plants

Exotic earthworms

Climate change

Altered precipitation

Increased $\mathrm{CO}_{2}$

Suburban sprawl 


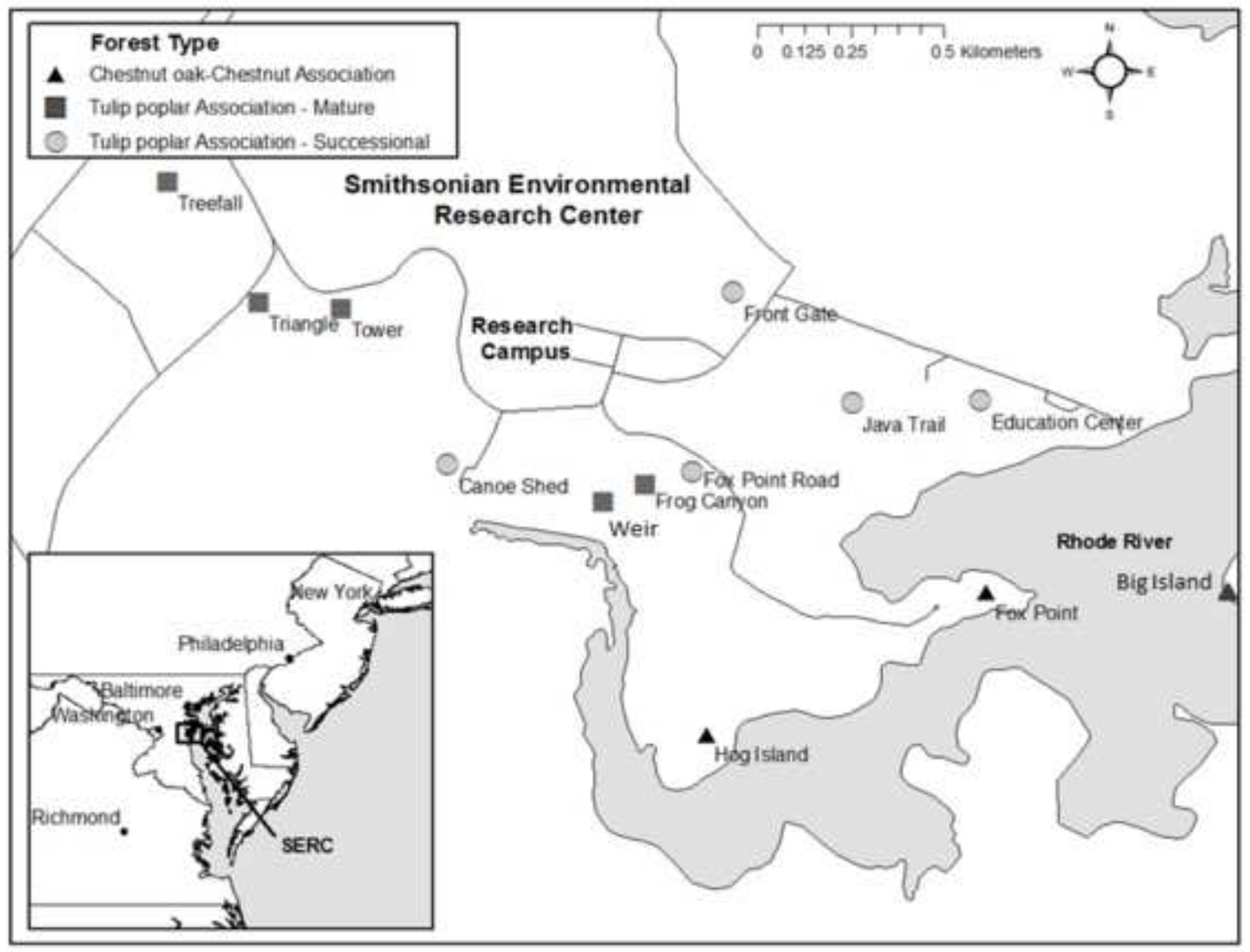




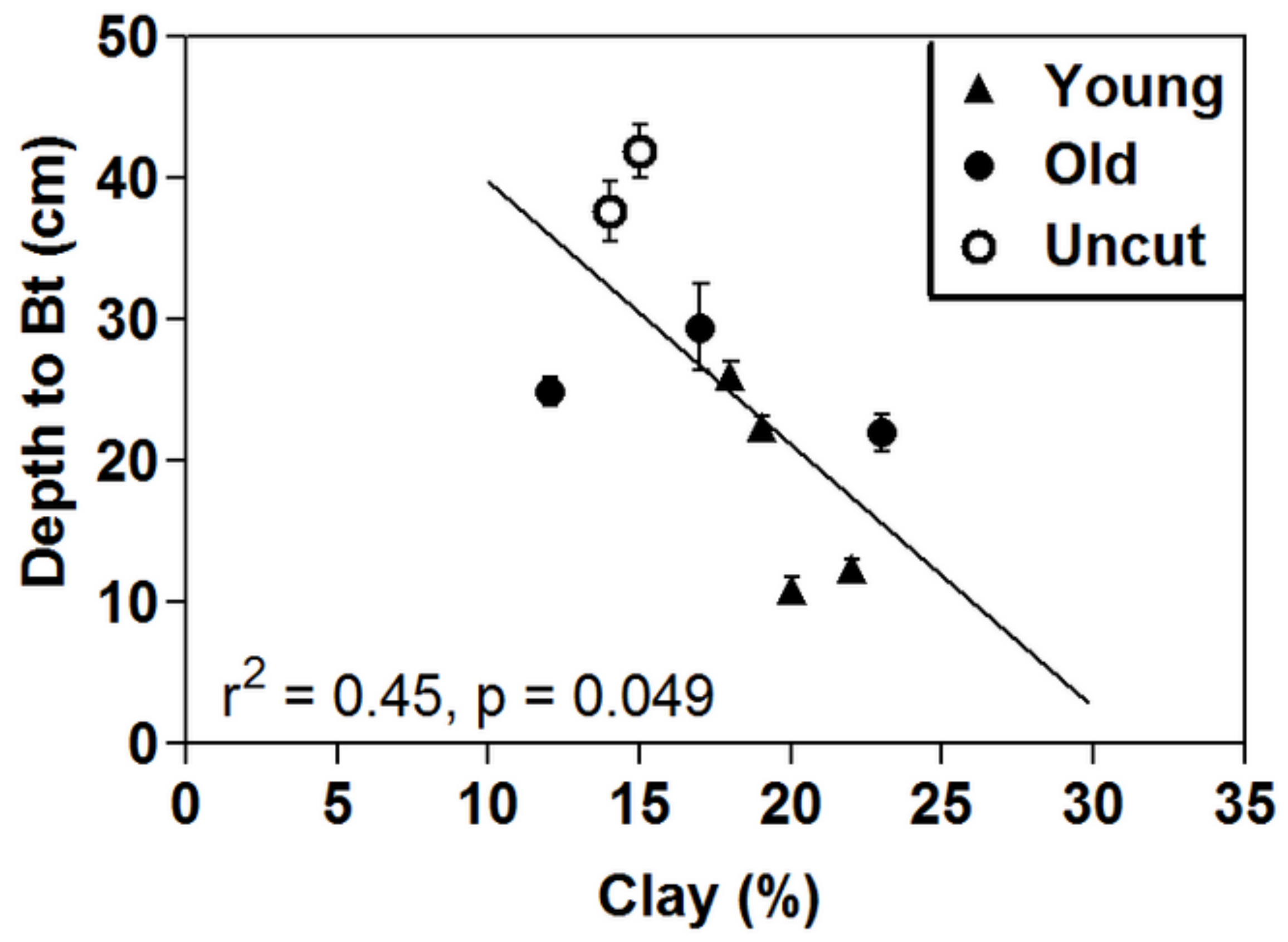




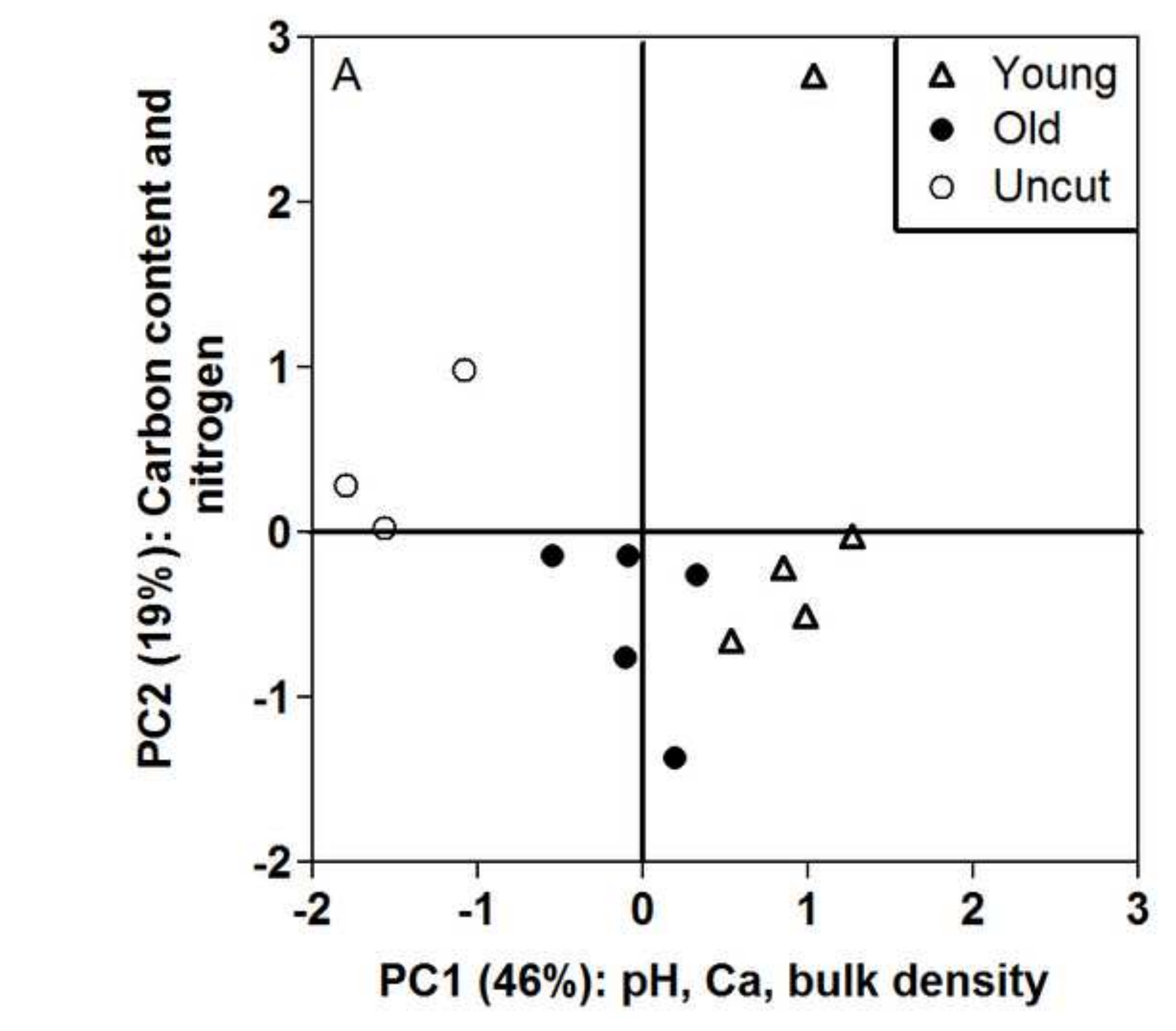




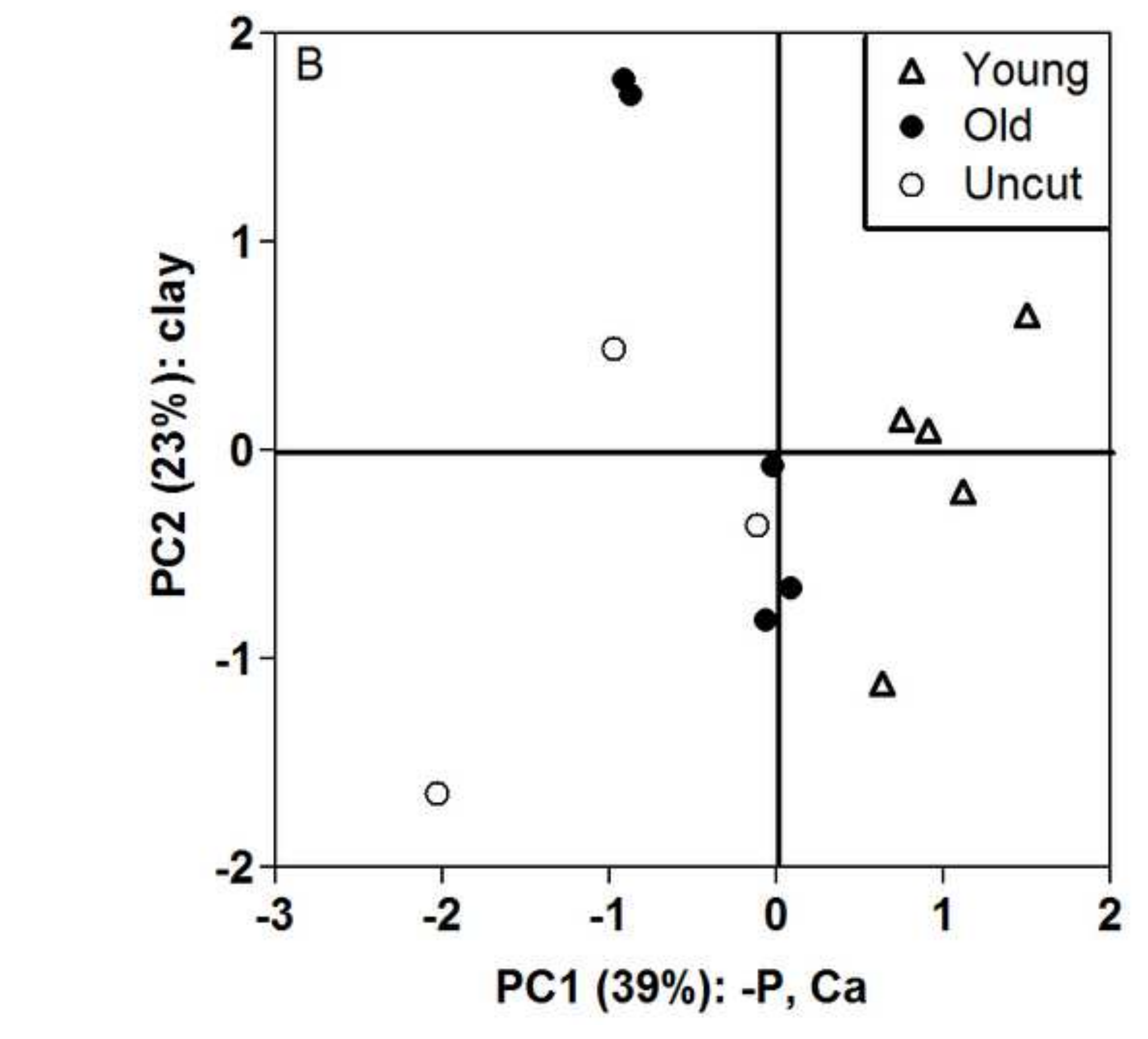




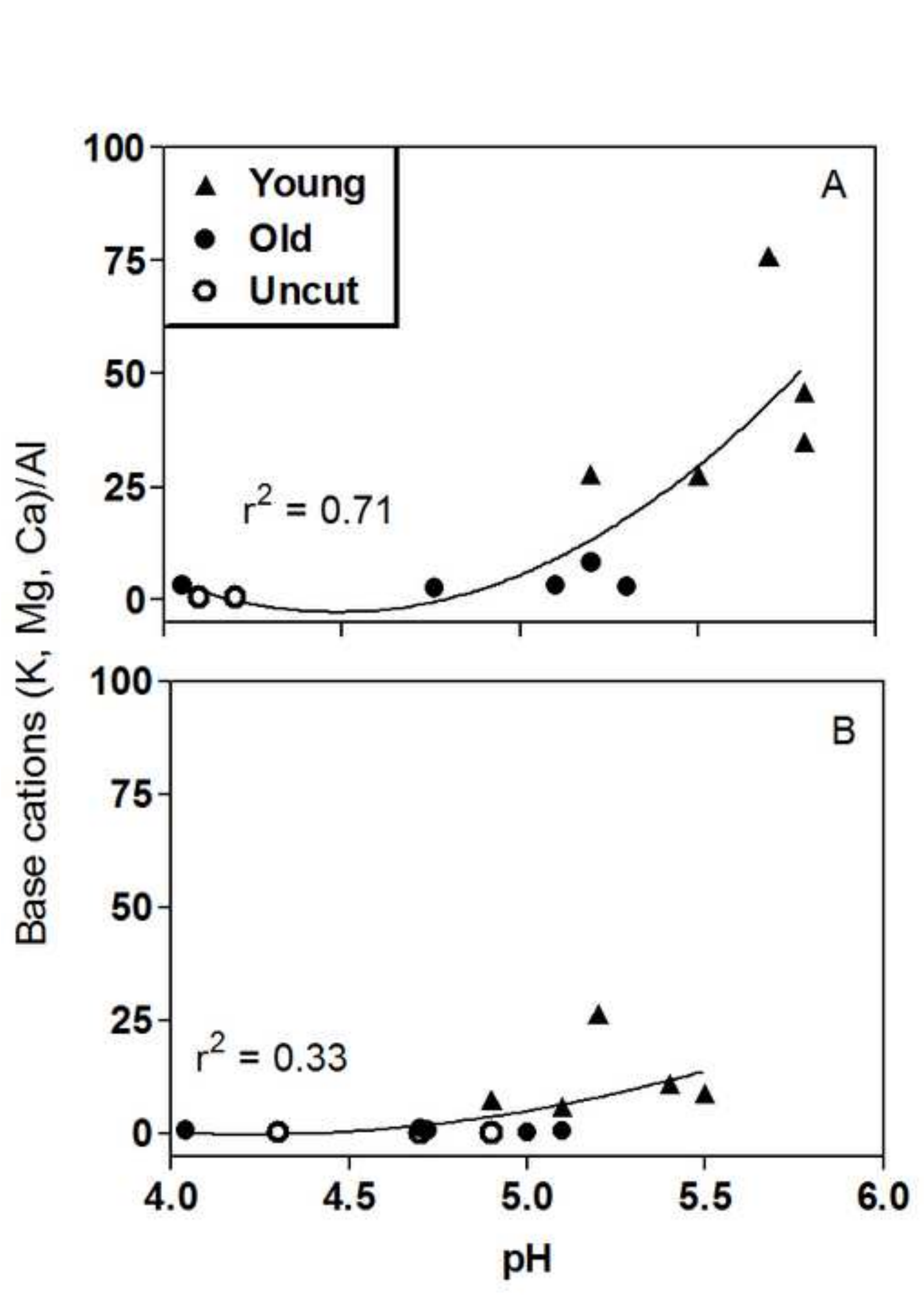

Figure 5

5

\section{.}

.
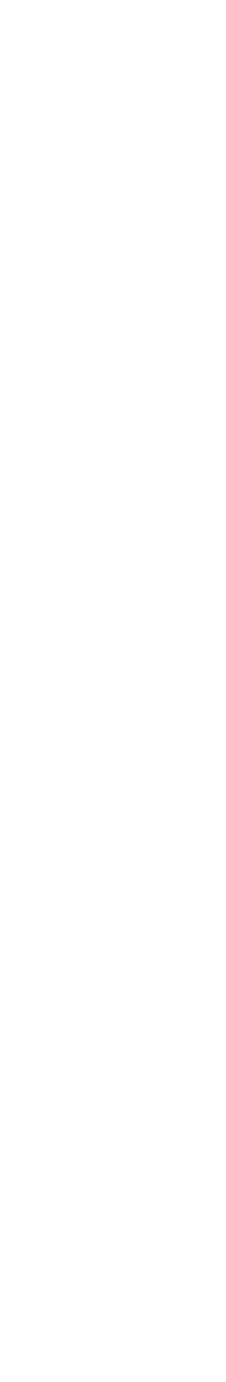

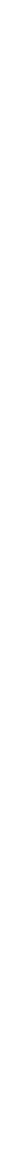

